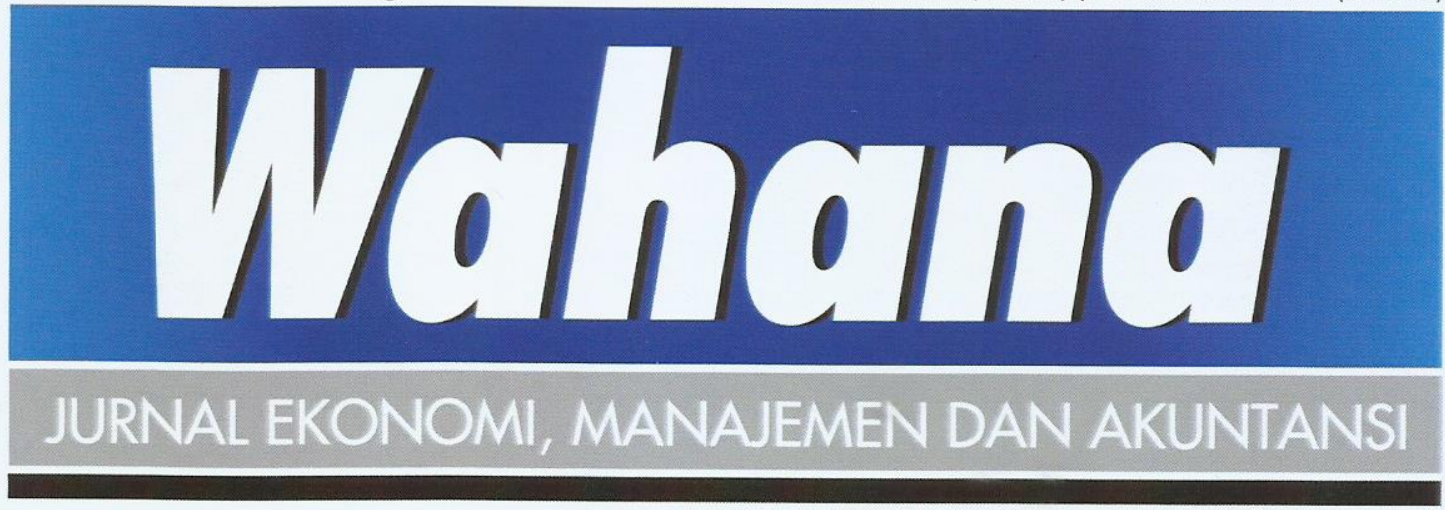

PENGUJIAN KECENDERUNGAN KECURANGAN AKUNTANSI ORGANISASI
PERANGKAT DAERAH DI PEMERINTAH DAERAH KABUPATEN SLEMAN Ratna Purnama Sari danYulita Ardiana

DEKONSTRUKSI KONSEP GOOD UNIVERSITY GOVERNANCE DALAM PELAKSANAAN ANGGARAN PERGURUANTINGGI NEGERI BADAN HUKUM Lussiana, Titik Mildawati dan Fidiana PENGUJIAN TERHADAP NIAT MAHASISWA DIPLOMA III AKUNTANSI
MENGIKUTI PELATIHAN BREVET PAJAK
Yanto Darmawan PENGUKURAN KINERJA PADA DINAS PERHUBUNGAN KABUPATEN MANDAILING NATAL BERBASIS BALANCED SCORECARD Heriyanti Tampubolon, Sri Muljaningsih dan Setyo Tri Wahyudi

AKUNTABILITAS DAN TRANSPARANSI PADA LAPORAN KEUANGAN PARTAI (Studi Kasus di Kantor DPD Partai Demokrat Provinsi Jawa Timur) Wiwid Widayanti, Maswar Patuh Priyadi dan Lilis Ardini DANA BANTUAN KEUANGAN PARTAI POLITIK DI SURAKARTA, SUDAHKAH TRANSPARAN DAN AKUNTABEL? Titik Setyaningsih, Andi Asrihapsari dan Doddy Setiawan

MENGAPA PERUSAHAAN ANJAK PIUTANG KURANG BERKEMBANG DI INDONESIA? (Dilihat Dengan Analisis Risk profile, Good Governance, Earning dan Capital (RGEC) Rani Eka Diansari dan Vidya Vitta Adhivinna MARKET OVERREACTION SAHAM LQ-45 TERHADAP PENGUMUMAN ASIAN GAMES KE- 18 Tatang Ary Gumanti, Mareita Dewi Kasprianti dan Ana Mufidah

\begin{tabular}{|c|c|c|c|c|c|c|}
\hline WAHANA & Volume 22 & No. 2 & Hal 73-203 & AGUSTUS 2019 & ISSN 1410-8224 (Cetak) & ISSN 2685-1415 (Online) \\
\hline
\end{tabular}




\section{SUSUNAN DEWAN REDAKSI WAHANA: JURNAL EKONOMI}

\section{Editor In Chief}

Krismiaji

Akademi Akuntansi YKPN Yogyakarta

Managing Editor

Supardi

Akademi Akuntansi YKPN Yogyakarta

\section{Editorial Boards}

Ani Sri Murwani

Akademi Akuntansi YKPN Yogyakarta

Y. Anni Aryani

Universitas Sebelas Maret Surakarta

Rusmin

Universitas Teknologi Yogyakarta

Dekeng Setyo Budiarto

Universitas PGRI Yogyakarta

Erna Setiany

Universitas Mercubuana Yogyakarta

Dwipraptono

Universitas Islam Indonesia Yogyakarta

Hermada Dekiawan

Akademi Akuntansi YKPN Yogyakarta

Yanto Darmawan

Akademi Akuntansi YKPN Yogyakarta

\section{Peer Reviewers}

Rahmawati Hanny Yustrianthe

Akademi Akuntansi YKPN Yogyakarta

Nung Harjanto

Akademi Akuntansi YKPN Yogyakarta

Surifah

Universitas Teknologi Yogyakarta

Amin Pujiati

Universitas Negeri Semarang

Dian Indri Purnamasari

UPN Veteran Yogyakarta

Intiyas Utami

Universitas Kristen Satya Wacana Salatiga

Totok Dewayanto

Universitas Diponegoro Semarang

Agus Suman

Universitas Brawijaya Malang

Bambang Agus Pramuka

Universitas Jenderal Soedirman Purwokerto

Saiful Muchlis

Universitas Negeri Alaudin Makasar
Bernardus Yuliarto Nugroho

Universitas Indonesia

Ni Putu Eka Widiastuti

UPN Veteran Jakarta

Hanif Ismail

Kwik Kian Gie School of Business

Carmel Meiden

Kwik Kian Gie School of Business

M. Nur A. Birton

Universitas Muhammadiyah Jakarta

M. Irfan Tarmizi

Universitas Muhammadiyah Jakarta

Indra Pahala

Universitas Negeri Jakarta

Herlin Tundjung

Universitas Tarumanegara Jakarat

\section{Layout Editor}

Saruda Widodo

Akademi Akuntansi YKPN Yogyakarta

\section{Assistant Editors}

Erlinda Nur Khasanah

Akademi Akuntansi YKPN Yogyakarta

Susanto Aimun

Akademi Akuntansi YKPN Yogyakarta

Pusat Penelitian dan Pengabdian Masyarakat

Akademi Akuntansi YKPN Yogyakarta

JI. Gagak Rimang No. 2-4 Balapan, Kotak Pos 6417 YKGK

Telp. (0274) 560159, 562317, 513413, 563516 


\section{DAFTAR ISI}

PENGUJIAN KECENDERUNGAN KECURANGAN AKUNTANSI ORGANISASI PERANGKAT DAERAH DI PEMERINTAH DAERAH KABUPATEN SLEMAN

Ratna Purnama Sari danYulita Ardiana

DEKONSTRUKSI KONSEP GOOD UNIVERSITY GOVERNANCE

DALAM PELAKSANAAN ANGGARAN PERGURUANTINGGI NEGERI BADAN HUKUM

Lussiana, Titik Mildawati dan Fidiana

PENGUJIANTERHADAP NIAT MAHASISWA DIPLOMA III AKUNTANSI

MENGIKUTI PELATIHAN BREVET PAJAK

Yanto Darmawan

PENGUKURAN KINERJA PADA DINAS PERHUBUNGAN

KABUPATEN MANDAILING NATAL BERBASIS BALANCED SCORECARD

Heriyanti Tampubolon, Sri Muljaningsih dan Setyo Tri Wahyudi

AKUNTABILITAS DANTRANSPARANSI PADA LAPORAN KEUANGAN PARTAI

(Studi Kasus di Kantor DPD Partai Demokrat Provinsi Jawa Timur)

Wiwid Widayanti, Maswar Patuh Priyadi dan Lilis Ardini

DANA BANTUAN KEUANGAN PARTAI POLITIK DI SURAKARTA, SUDAHKAHTRANSPARAN DAN AKUNTABEL?

Titik Setyaningsih, Andi Asrihapsari dan Doddy Setiawan

MENGAPA PERUSAHAAN ANJAK PIUTANG KURANG BERKEMBANG DI INDONESIA?

(Dilihat Dengan Analisis Risk profile, Good Governance, Earning dan Capital (RGEC)

Rani Eka Diansari dan Vidya Vitta Adhivinna

MARKET OVERREACTION SAHAM LQ-45

TERHADAP PENGUMUMAN ASIAN GAMES KE- 18

Tatang Ary Gumanti, Mareita Dewi Kasprianti dan Ana Mufidah 


\title{
MENGAPA PERUSAHAAN ANJAK PIUTANG KURANG BERKEMBANG DI INDONESIA? (Dilihat Dengan Analisis Risk profile, Good Governance, Earning dan Capital (RGEC))
}

\author{
Rani Eka Diansari ${ }^{1}$, Vidya Vitta Adhivinna ${ }^{2}$ \\ Fakultas Ekonomi, Universitas PGRI Yogyakarta ${ }^{1,2}$ \\ $\underline{\text { ranieka@upy.ac.id }}^{1}$
}

\begin{abstract}
Factoring Company is one of the financial institutions in Indonesia. Factoring Company is a company that serves to take over the receivables that occur in buying and selling transactions so as not to cause serious problems in the company's cash flow. Risk can be avoided very minimally and the company can greatly help avoid a problem related to its uncollectible trade through financial institutions with factoring concept (Aprianto, 2017). Based on the concept of factoring, actually the existence of the company factoring is very profitable for companies especially trading companies, but if looking at the data in Indonesia is still very little of the company's sustainability factoring, the evidence can be seen on the Indonesian stock exchange, with less than 100 companies factoring listed on the stock exchanges. It shows that in Indonesia the company factoring is very less developed. With these conditions, the author is interested to see the cause of the company factoring is not developed well from the analysis of risk profile, good governance, earning and Capitalnya, although RGEC is prevalent in banking industry but because Consideration of the activities of the company to be receivables some have the same characteristics as banking then the authors tried to analyze with RGEC analysis by the detailed risk profile not only based on the ratio of LDR and NPL Were. The object in this study was the factoring company listed on the Indonesia Stock exchange in 2017 and examined by a qualitative method of descriptive. Results of the research can be concluded there are several factors that cause the company to factor less developed in Indonesia including the inherent risk of credit, human resources, regulation, and public trust because the factoring isn't famous
\end{abstract}

Keywords: Factoring, RGEC.

\begin{abstract}
ABSTRAK
Perusahaan anjak piutang merupakan salah satu lembaga keuangan di Indonesia. Perusahaan Anjak Piutang berfungsi untuk mengambil alih piutang yang terjadi dalam transaksi jual beli agar tidak menimbulkan masalah serius dalam arus kas perusahaan. Risiko perusahaan dapat dihindari dan perusahaan dapat terbantu menghindari masalah yang berkaitan dengan perdagangan yang tidak tertagih melalui lembaga keuangan dengan konsep anjak (Aprianto, 2017). Berdasarkan konsep anjak piutang, sebenarnya keberadaan perusahaan anjak piutang sangat menguntungkan bagi perusahaan khususnya perusahaan perdagangan, akan tetapi jika melihat dari data di Indonesia masih sangat sedikit jumlah perusahaan anjak piutang, terbukti dapat dilihat di Bursa Efek Indonesia, dengan kurang dari 100 perusahaan anjak piutang yang terdaftar di Bursa saham. Hal ini menunjukkan bahwa di Indonesia anjak piutang sangat kurang berkembang. Dengan kondisi ini, penulis tertarik untuk melihat penyebab perusahaan anjak tidak berkembang dengan baik dari analisis profil risiko, good governance, earning dan capitalnya, meskipun rgec lazimnya digunakan dalam industri perbankan tetapi karena pertimbangan kegiatan perusahaan anjak piutang dan bank memiliki karakteristik yang sama seperti perbankan maka penulis mencoba untuk menganalisa dengan analisis RGEC tetapi tidak hanya berdasarkan rasio LDR dan NPL
\end{abstract}


melainkan secara rinci pada profil resiko yang melekat. Obyek dalam penelitian adalah perusahaan anjak piutang yang tercatat di Bursa Efek Indonesia pada 2017 dan diteliti dengan metode deskriptif secara kualitatif. Hasil penelitian dapat disimpulkan ada beberapa faktor yang menyebabkan perusahaan menjadi faktor kurang berkembang di Indonesia termasuk risiko inheren kredit, sumber daya manusia, regulasi, dan kepercayaan publik karena anjak piutang tidak begitu dikenal.

Kata kunci: anjak piutang, RGEC.

\section{PENDAHULUAN}

Menghadapi persaingan bisnis di era digital dan fintech seperti saat ini yang begitu dinamis, sehingga memaksa pelaku usaha selalu berusaha untuk melakukan bermacam inovasi produk maupun sistem penjualan untuk dapat meningkatkan omset perusahaan. Berbagai macam upaya dilakukan untuk dapat menaikkan keuntungan dan omset penjualan, salah satu diantaranya adalah memperluas pasar serta memenuhi permintaan dan kebutuhan pelanggan. Salah satu usaha yang dilakukan oleh pelaku usaha dalam rangka memenuhi permintaan pelanggan adalah dengan mempermudah syarat dan cara pembayaran produk yang diperjual belikan. Mempermudah tata cara pembayaran salah satu diantaranya adalah pembayaran secara bertahap atau tempo. Cara pembayaran kredit atau tempo memang dinilai efektif untuk meningkatkan omset penjualan suatu produk, akan tetapi cara tersebut bukan tidak beresiko. Terdapat beberapa resiko yang akan diamani oleh perusahaan ketika memilih syarat pembayaran tempo atau kredit tanpa melibatkan lembaga keuangan seperti Bank, hal tersebut dikarenakan tidak adanya barang jaminan yang menjamin kelancaran pembayaran pelanggan. Selain itu penjualan kredit atau tempo juga akan mengganggu cashflow jika kondisi kas perusahaan tidak dalam kondisi yang surplus. Jika resiko penjualan kredit itu terjadi, dan piutang gagal tertagih maka akan mendatangkan masalah pendanaan yang serius bagi perusahaan.

Untuk mengatasi segala permasalahan tersebut sebenarnya perusahaan dapat mengambil sebuah pilihan yaitu melakukan penjualan faktur piutangnya atau melakukan pengalihan faktur piutang pada sebuah lembaga keuangan yang dikenal dengan nama lembaga anjak piutang. Perusahaan Anjak merupakan sebuah perusahaan yang berfungsi mengambil alih piutang yang terjadi atas transaksi jual beli agar tidak menimbulkan permasalahan serius pada aliran kas perusahaan. Risiko dapat dihindari dengan sangat minimal serta perusahaan dapat sangat terbantu menghindari sebuah masalah terkait dengan piutang dagangnya yang tidak tertagih melalui lembaga keuangan dengan konsep anjak piutang (factoring) (Aprianto, 2017). Pada akhir tahun 1988an, perusahaan yang bergerak di industry anjak piutang mulai dikenal di Indonesia, hal tersebut sejak berlakunya KepPres Nomor 61 Tahun 1988 yang menjelaskan tentang Ketentuan dan Tata Cara Pelaksanaan Lembaga Pembiayaan. Perusahaan Anjak Piutang (factoring) menurut KepPres Nomor 61 Tahun 1988 berbunyi "Perusahaan anjak piutang merupakan pembiayaan dalam bentuk dan/atau pengalihan serta pengurusan piutang atau tagihan jangka pendek suatu perusahaan dari transaksi perdagangan dalam dan luar negeri““.

Berdasarkan konsep anjak piutang yang dijabarkan dalam kepPres Nomor 61 Tahun 1998 tersebut, sebenarnya keberadaan perusahaan anjak piutang ini sangat menguntungkan untuk perusahaan khususnya perusahaan dagang, perusahaan dagang sebagai sebuah perusahaan yang hampir seluruh aktivitas usahanya berkaitan dengan piutang pihak ketiga, karena memang piutang yang muncul dari penjualan kredit dibutuhkan untuk menaikkan omset penjualannya sangat membutuhkan perusahaan anjak 
piutang untuk mengakomodir piutang piutangnya yang berjangka waktu relatif panjang ataupun piutang piutang usahanya yang belum mampu tertagih sesuai jadwal sementara perusahaan juga dihadapkan dengan kepentingan cashflow kegiatan operasional yang harus terus berjalan.

Jika melihat dari kepentingan perusahaan dagang tersebut mestinya bisnis anjak piutang menjadi sebuah bisnis yang menguntungkan karena banyak yang membutuhkan, dapat kita lihat sendiri bahwa banyak perusahaan dagang berkembang di indonesi baik yang listed di bursa Efek Indonesia ataupun perusahaan tertutup, akan tetapi ironisnya di Indonesia masih sangat sedikit sekali keberaan perusahaan anjak piutang, bukti tersebut bisa kita lihat di Bursa Efek Indonesia, masing kurang dari 100 perusahaan anjak piutang yang listed di bursa saham. Hal tersebut menunjukkan bahwa di Indonesia perusahaan Anjak Piutang sangat kurang berkembang. Dengan kondisi tersebut penulis tertarik untuk melihat penyebab perusahaan anjak piutang tidak berkembang dengan baik dari analisis risk profile, good governance, earning dan capital (RGEC) untuk masing-masing perusahaan anajak piutang.

Analisis RGEC memang lazim digunakan untuk industry perbankan dan belum lazim digunakan untuk lembaga keuangan lain non Bank akan tetapi jika dilihat dari karakteristik usahanya dalam hal menyalurkan dana kepada pihak lain, kegiatan perusahaan ajak piutang beberapa memiliki karakteristik yang hampir sama dengan perbankan. Oleh karena itu penulis ingin mencoba menganalisis perusahaan anjak piutang dengan analisis RGEC dengan mencoba mendiskripsikan risk profile secara mendetail tidak hanya berdasarkan rasio LDR dan NPL saja akan tetapi mendalam termasuk pada resiko inheren secara mendalam berdasarkan delapan resiko yang melekat diantaranya risiko kredit, risiko pasar, risiko likuiditas, risiko operasional, risiko hukum, risiko stratejik, risiko kepatuhan dan risiko reputasi

\section{LANDASAN TEORI}

\section{Anjak Piutang (Factoring)}

Anjak piutang (factoring) merupakan salah satu dari sekian banyak lembaga keuangan yang merupakan lembaga pembiayaan berdasarkan KepPres Nomor 61 Tahun 1988 tentang Lembaga Pembiayaan, yang ditindak lanjuti dengan Keputusan Menteri Keuangan Republik Indonesia Nomor 1251/KMK.013/1988 tentang Ketentuan dan Tata Cara Pelaksanaan Lembaga Pembiayaan. Kasmir (2014) mengidentifikasikan bahwa perusahaan anjak piutang merupakan perusahaan yang kegiatannya usaha utamanya melakukan penagihan dan atau pembelian, atau melakukan pengambilalihan, pengelolaan utang piutang suatu perusahaan yang berasal dari transaksi penjualan perusahaan dengan imbalan. Menurut penggolongannya perusahaan anjak piutang dibedakan menjadi Berdasarkan Pemberitahuan, Berdasarkan Tanggung Jawab, Berdasarkan Pelanggan, dan Berdasarkan Wilayah.

Perusahaan anjak piutang berdasarkan pemberitahuan dibedakan menjadi Disclosed dan Undisclosed. Untuk perusahaan anjak piutang berdasarkan tanggung jawba dibedakan menjadi Withrecourse dan Without recourse. Penggolongan perusahaan anjak piutang berdasarkan pelanggan dibedakan menjadi Full service factoring, Resource factoring, Bulkfactoring, Maturity factoring, Invoice discounting, Undisclosed factoring, Advance Payment. Sedangkan penggolongan perusahaan anjak piutang berdasarkan 
wilayah dibedakan menjadi Domestic Factoring dan International Factoring. Adapun hal-hal yang terkait dengan perusahaan anjak piutang dapat dijabarkan dalam Tabel 1 .

\section{Tabel 1. Hal-hal Terkait Anjak Piutang}

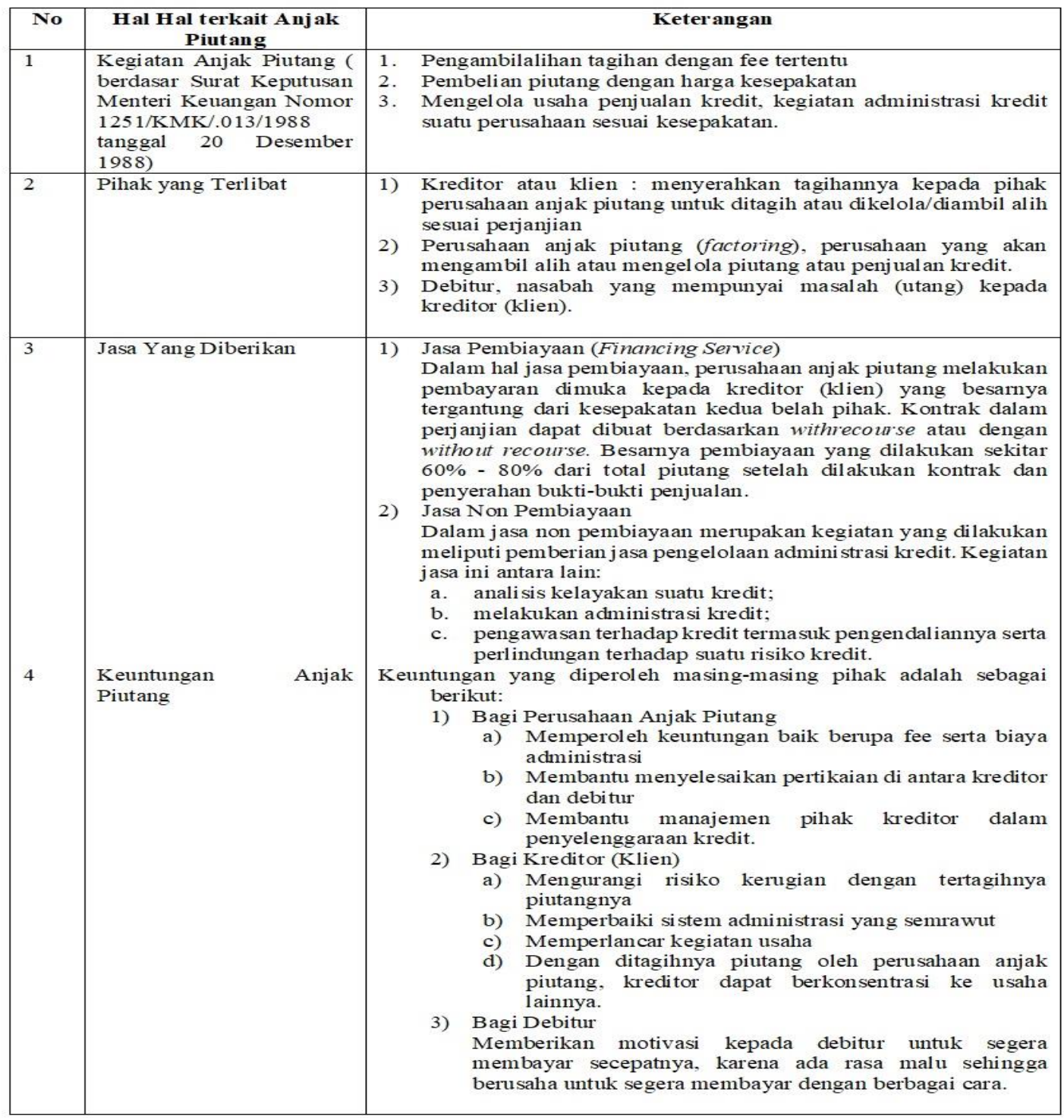

\section{Perbankan}

Secara umum dapat dikatakan, bahwa Bank sebagai lembaga keuangan menjadi pihak perantara bagi sektor rumah tangga dan sektor industri, khususnya di dalam menyerap dana dari sektor rumah tangga dalam bentuk tabungan dan menyalurkannya kepada sektor industri sebagai kredit investasi. Meskipun dalam prakteknya penyerapan dan penyaluran dana itu sendiri dapat terjadi baik di dan untuk sektor rumah tangga maupun sektor industri. Menurut UU Nomor 10 Tahun 1998 yang disyahkan tanggal 10 November 1998 tentang Perbankan, yang dimaksud dengan bank adalah badan usaha yang menghimpun dana dari masyarakat dalam bentuk simpanan dan menyalurkannya 
kepada masyarakat dalam bentuk kredit dan atau bentuk-bentuk lainnya dalam rangka meningkatkan taraf hidup rakyat banyak. Dari pengertian di atas dapat dijelaskan secara lebih luas lagi bahwa bank merupakan perusahaan yang bergerak dalam bidang keuangan, artinya aktivitas perbankan selalu berkaitan dalam bidang keuangan (Wiwoho, 2014). Atas dasar segala aktivitas yang terkait dengan bidang keuangan maka Bank Indonesia menetapkan prinsip kesehatan perbankan dengan metode Risk Profile, Good Governance, Earning, Capital (RGEC) untuk menilai kinerja dan kesehatan perbankan.

\section{Risk Profile, Good Governance, Earning, Capital (RGEC)}

Risk Profile, Good Governance, Earning, Capital (RGEC) yang selama ini dikenal merupakan metode penilaian kesehatan lembaga keuangan khususnya perbankan. Metode RGEC ditetapkan melalui Surat Edaran Bank Indonesia No.13/24/DPNP tanggal 25 oktober 2011 yang kemudian disempurnakan oleh Otoritas Jasa keuangan dengan Surat Edaran Otoritas Jasa Keuangan No.10/SEOJK.03/2014. Akan tetapi metode RGEC dalam penelitian ini akan mencoba digunakan untuk menilai tingkat kesehatan lembaga keuangan lainnya yaitu Perusahaan anjak piutang. Metode RGEC khususnya yang terkait dengan profil risiko memberikan penjelasan mengenai risiko yang kemungkinan dihadapi oleh perusahaan anjak piutang, seperti risiko kredit, risiko pasar, risiko likuiditas, risiko operasional, risiko hukum, risiko stratejik, risiko kepatuhan dan risiko reputasi. Risiko kredit merupakan sebuah risiko yang terjadi akibat debitur dan/atau pihak lain dalam memenuhi kewajiban kepada debitur.

Risiko Pasar merupakan Risiko yang muncul dan dapat dilihat dari posisi neraca dan rekening administratif termasuk transaksi derivatif, akibat perubahan dari kondisi pasar, termasuk Risiko perubahan harga option. Risiko pasar meliputi Risiko suku bunga, Risiko nilai tukar, Risiko ekuitas, dan risiko komunitas. Risiko Likuiditas merupakan Risiko yang muncul karena ketidakmampuan Bank untuk memenuhi kewajiban yang jatuh tempo dalam jangka pendek dari sumber pendanaan arus kas, dan/atau dari aset likuid berkualitas tinggi yang dapat diagunkan, tanpa mengganggu aktivitas dan kondisi keuangan dari perusahaan anjak piutang itu sendiri. Risiko Operasional merupakan Risiko yang terjadi karena ketidakcukupan dan/atau tidak berfungsinya proses internal, kesalahan manusia, kegagalan sistem, dan/atau adanya kejadian eksternal yang mempengaruhi operasional perusahaan anjak piutang.

Risiko Hukum merupakan Risiko yang timbul akibat dari tuntutan hukum dan/atau kelemahan aspek yuridis. Risiko ini juga dapat timbul antara lain karena ketiadaan peraturan perundang-undangan yang mendasari atau kelemahan perikatan yang ditetapkan oleh pihak yang terkait. Risiko Stratejik merupakan Risiko yang terjadi karena ketidaktepatan perusahaan anjak piutang dalam mengambil sebuah keputusan yang terkait dengan bisnis proses dan/atau pelaksanaan suatu keputusan stratejik serta kegagalan dalam mengantisipasi perubahan lingkungan bisnis yang ada. Risiko Kepatuhan merupakan Risiko yang timbul akibat dari lembaga anjak piutang tidak mematuhi dan/atau tidak melaksanakan peraturan perundang-undangan dan ketentuan yang berlaku dalam hal ini adalah regulasi yang ditetapkan oleh pemerintah dan otoritas jasa keuangan. Sumber risiko kepatuhan antara lain timbul karena kurangnya pemahaman atau kesadaran hukum terhadap ketentuan maupun standar bisnis yang berlaku umum. Risiko Reputasi merupakan Risiko yang muncul karena akibat menurunnya tingkat kepercayaan stakeholder yang bersumber dari persepsi negatif 
terhadap lembaga keuangan anjak piutang dan mungkin keberadaannya yang kurang dikebnal di masyarakat.

\section{Good Corporate Governance (GCG)}

Penilaian terhadap faktor GCG dalam metode RGEC didasarkan ke dalam tiga aspek utama yaitu, governance structure, governance process, dan governance output. Governance stucture mencakup pelaksanaan tugas dan tanggung jawab Dewan Komisaris dan Dewan Direksi serta kelengkapan dan pelaksanaan tugas komite. Governance process mencakup fungsi kepatuhan, penanganan benturan kepentingan, penerapan fungsi audit intern dan ekstern, penerapan manajemen risiko termasuk sistem pengendalian intern, penyediaan dana kepada pihak terkait dan dana besar, serta rencana strategis bank. Aspek terakhir governance output mencakup transparansi kondisi keuangan dan non keuangan, laporan pelaksanaan GCG yang memenuhi prinsip Transparancy, Accountability, Responsibility, Indepedency, dan Fairness (TARIF)".

\section{Earnings (Rentabilitas)}

Berdasarkan Surat Edaran Bank Indonesia Nomor 13/24/DPNP tanggal 25 oktober 2011, penilaian terhadap faktor rentabilitas diukur dengan beberapa parameter/indikator. Namun dalam penelitian ini rentabilitas Bank Sinar Harapan Bali hanya diukur melalui dua faktor, yaitu Return on asset (ROA) dan Net interest margin (NIM). Hal ini dikarenakan data yang diperoleh yang mengacu pada indikator parameter rentabilitas, tidak diperoleh.“

\section{Capital (Permodalan)}

Capital Adequacy Ratio (CAR) merupakan rasio kinerja yang biasanya digunakan oleh perusahaan lembaga keuangan khususnya perbankan untuk mengukur kecukupan modal yang dimiliki guna mendukung aktiva yang mengandung atau menghasilkan risiko, akan tetapi dalam hal ini CAR digunakan untuk menilai rasio kecukupan modal perusahaan anjak piutang. CAR merupakan rasio yang memperlihatkan sejauh mana seluruh aktiva yang dimiliki oleh perusahaan anjak piutang yang mengandung risiko.

\section{METODE PENELITIAN}

Penelitian ini merupakan tipe penelitian deskriptif kualitatif. Dalam penelitian ini berusaha mendeskripsikan gambaran mengenai fenomena yang terjadi mengapa perusahaan anjak piutang tidak berkembang dengan baik di Indonesia. Dalam penelitian ini penulis akan menjelaskan hasil penelitian, dengan cara mendiskripsikan kondisi perusahaan anjak piutang dengan menganalisa perusahaan anjak piutang yang ada di Indonesia berdasarkan laporan keuangannya dengan metode REGC. Metode RGEC biasanya dinilai untuk kesehatan perbankan, akan tetapi dalam hal ini peneliti mencoba untuk melalukan penelitian pada lembaga keuangan lain yang tipikalnya dinilai mirip dengan Perbankan. Metode RGEC digunakan untuk mencoba menjawab mengapa perusahaan anjak piutang kurang berkembang di Indonesia. Sehingga alat analisis yang digunakan dalam penelitian ini adalah: 


\section{Risiko Kredit}

Dalam menilai Risiko inheren atas Risiko Kredit, parameter/indikator yang digunakan diantaranya adalah komposisi portofolio aset dan tingkat konsentrasi; kualitas penyediaan dana dan kecukupan pencadangan; strategi penyediaan dana $\mathrm{d}$ an sumber timbulnya penyediaan dana serta faktor eksternal yang mempengaruhi kredit tidak terbayar sesuai dengan seharusnya.

\section{Risiko Pasar}

Indikator Resiko Pasar yang dijabarkan di dalam penelitian ini dengan volume dan komposisi portofolio, kerugian potensial (potential loss) Risiko Suku Bunga dala Banking Book (Interest Rate Risk in Banking Book-IRRBB) dan strategi dan kebijakan bisnis. Banking Book dalam hal ini tetap diperhitungkan karena pembebanan bunga atau bagu hasil anjak piutang juga mengacu pada bunga perbankan.

\section{Risiko Likuiditas}

Dalam menilai Risiko inheren atas Risiko Likuiditas, parameter yang digunakan adalah komposisi dari aset, kewajiban, dan transaksi rekening administrative, konsentrasi dari aset dan kewajiban, kerentanan pada kebutuhan pendanaan; dan akses pada sumber-sumber pendanaan.

\section{Risiko Operasional}

Dalam menilai Risiko inheren atas Risiko Operasional, parameter/indikator yang digunakan diantaranya

adalahkarakteristik dan kompleksitas bisnis; sumber daya manusia; teknologi informasi dan infrastruktur pendukung; fraud, baik internal maupun eksternal, dan kejadian eksternal.

\section{Risiko Hukum}

Dalam menilai Risiko inheren atas Risiko Hukum, parameter/indikator yang digun akan diantaranya faktor litigasi; faktor kelemahan perikatan; dan faktor ketiadaan/perubahan peraturan perundang-undangan.

\section{Risiko Stratejik}

Dalam menilai Risiko inheren atas Risiko Stratejik, parameter/indikator yang digunakan adalah: kesesuaian strategi bisnis Bank dengan lingkungan bisnis; strategi berisiko rendah dan berisiko tinggi; posisi bisnis perusahaan anjak piutang dibandingkan perusahaan anjak piutang lain serta perusahaan lain yang sama sama lembaga keuangan; dan pencapaian rencana bisnis Bank.

\section{Risiko Kepatuhan}

Dalam menilai Risiko inheren atas Risiko Kepatuhan, parameter/indikator yang di gunakan

jenis dan signifikansi pelanggaran yang dilakukan, frekuensi pelanggaran yang dilakukan atau track record, ketidakpatuhan lembaga anjak piutang, dan pelanggaran terhadap ketentuan bisnis terkait dengan transaksi keuangan.

\section{Risiko Reputasi}

Dalam menilai Risiko inheren atas Risiko Reputasi, parameter atau indikator yang digunakan adalah, pengaruh reputasi negatif dari pemilik Bank dan perusahaan 
terkait; pelanggaran etika bisnis; kompleksitas produk dan kerjasama bisnis Bank frekuensi, materialitas, dan eksposur pemberitaan negatif Bank; dan frekuensi dan materialitas keluhan nasabah.

\section{Good Corporate Governance}

Good Corporate Governance tercermin dari prinsip-prinsip yang diterapkan oleh perusahaan untuk mengoptimalkan nilai perusahaan, meningkatkan performance dan menaikkan kontribusi perusahaan di masyarakat, serta menjaga going concern perusahaan secara jangka panjang. Good Corporate Governance dalam penelitian ini dijabarkan dengan melihat dari tiga aspek yaitu struktur dari perusahaan, proses yang dilakukan oleh perusahaan, serta indikator outcome yang ingin dicapai mencapai tujuan yang diharapkan oleh perusahaan.

\section{Earning}

Earning dalam analisis RGEC adalah sebuah kinerja yang indikatornya adalah laba, untuk menganalisa kinerja dari earning dalam penelitian ini menggunakan rasio ROA yang diukur dengan rumusan sbb :

$$
\text { Return On Assets (ROA) }=\frac{\text { Laba bersib aetelah pajak }}{\text { total Asset }} \times 100 \%
$$

\section{Net Interest Margin (NIM)}

Dalam penelitian ini NIM diukur dengan menggunakan rumus sebagai berikut:

\section{$\mathrm{NIM}=($ Pendapatan bunga bersih dibagi rata-rata aktiva produktif $) \times 100 \%$}

\section{Capital}

Diukur dengan rumusan :

$$
\text { CAR }=\frac{\text { Modal Sendiri }}{\text { ATMIR }} \times 100 \%
$$

Dimana:

CAR : Capital Adequacy ratio

ATMR : Aktiva Tertimbang Menurut Rata-rata

\section{HASIL DAN PEMBAHASAN \\ Diskripsi Data}

Data yang diambil sebagai objek penelitian hanya Data Laporan Keuangan terbaru yaitu data tahun 2017, dan hanya berjumlah 10 ( sepuluh ) perusahaan dari 14 ( empat belas perusahaan ), hal tersebut berdasarkan pertimbangan perusahaan tidak delisting selama periode penelitian tahun 2013-2017 dan Perusahaan memiliki laba positif selama periode 
penelitian tahun 2013 sampai 2017. Perusahaan Anjak Piutang yang dijadikan objek penelitian tersaji pada Tabel 2 berikut.

Tabel 2. Perusahaan Anjak Piutang

\begin{tabular}{clc}
\hline NO & \multicolumn{1}{c}{ NAMA PERUSAHAAN } & KODE \\
\hline 1 & Adira Dinamika Multifinance Tbk & ADMF \\
2 & Buana Finance Tbk & BBLD \\
3 & Batavia Prosperindo Finance Tbk & BPFI \\
4 & Clipan Finance Indonesia Tbk & CFIN \\
5 & Danasupra Erapacific Tbk & DEFI \\
6 & Radana Bhaskara Finance Tbk & HDFA \\
7 & Mandala Multifinance Tbk & MFIN \\
8 & Tifa Finance Tbk & TIFA \\
9 & Verena Multifinance Tbk & VRNA \\
10 & BFI Finance Indonesia Tbk & BFIN \\
\hline
\end{tabular}

\section{Pembahasan}

Penelitian ini menggunakan metode Risk Profile, Good Governance, Earning, Capital (RGEC) dalam menjelaskan pertanyaan yang diajukan dalam penelitian ini. Hasil analisa metode RGEC tersebut dapat terlihat dalam penjelasan berikut ini:

\section{Risk Profile}

Untuk dapat melihat tingkat kesehatan berdasarkan profil resiko yang dimiliki lembaga anjak piutang, terdapat 8 (delapan) profil resiko diantaranya:

\section{Risiko Kredit}

Lembaga keuangan Anjak Piutang merupakan Lembaga Keuangan yang menjalankan fungsinya sebagai suatu lembaga yang berfungsi mengambil alih piutang nasabah baik kategori piutang bermasalah maupun piutang yang diambil alih karena klien melakukan ketidak tepatan pemberian piutang sehingga klien mengalami kendala dalam arus kas perusahaan. Jika dilihat dari data lembaga anjak piutang tahun 2017 menunjukkan bahwa resiko kredit yang dihadapi Perusahaan anjak Piutang cukup besar akan tetapi di tahun 2017 porsi penyaluran kredit 16,42 \% jika dibandingkan tahun 2016 yaitu mencapai 22,69 Miliar di tahun 2017.

\section{Risiko Pasar}

Ketua asosiasi perusahaan pembiayaan Indonesia (APPI), menyampaikan bahwa portofolio pembiayaan secara total Perusahaan Anjak Piutang masih sangat kecil dibandingkan perusahaan pembiayaan lainnya terutama dalam pembiayaan Multiguna. Munculnya Fintech di akhir akhir tahun 2017 juga menjadi sebuah tantangan tersendiri untuk perusahaan anjak piutang. Sebelum marah fintech saja kita dapat melihat bahwa gaung bisnis perusahaan anjak piutang di Indonesia bisa dikatakan kurang menggelora.

\section{Risiko Likuiditas}

Berdasarkan data terkait dengan current ratio yang dihitung dari perusahaan anjak piutang menunjukkan bahwa perusahaan anjak piutang dapat dikatakan rata-rata 
mempunyai kemampuan untuk melunasi kewajiban jangka pendeknya atau bisa dikatakan Likuid karena nilai perhitungan current rasio menunjukkan angka diatas 1 . Hal tersebut tersaji dalam Tabel 3 berikut ini.

Tabel 3. Perhitungan Current Ratio

\begin{tabular}{rcc}
\hline \multicolumn{1}{c}{ No } & Kode & Current Ratio \\
\hline 1 & ADMF & 1,132 \\
2 & BBLD & 1,211 \\
3 & BPFI & 2,568 \\
4 & CFIN & 1,333 \\
5 & DEFI & 2,846 \\
6 & HDFA & 1,195 \\
7 & MFIN & 2,902 \\
8 & TIFA & 1,204 \\
9 & VRNA & 1,412 \\
10 & BFIN & 2,186 \\
\hline
\end{tabular}

\section{Risiko Operasional}

Berdasarkan acuan pada Perbankan kita bisa melihat resiko operasional dititik beratkan oleh potensi Sumber Daya Manusia, dalam sebuah kesempatan yang dimuat dalam bisnis.com Ketua asosiasi perusahaan pembiayaan Indonesia (APPI), menyampaikan bahwa persoalan sumber daya manusia memberikan kontribusi cukup besar perkembangan anjak piutang. Dilihat dari risiko inherennya bahwa perusahaan pembiayaan seperti perusahaan anjak piutang, beriko tinggi karena bisa dikatakan kredit tanpa agunan, karena agunannya adalah piutang yang berasal dari persediaan atau bisa dikatakan piutang Modal kerja, maka membutuhkan SDM yang memang benar benar mampu melakukan analisis agar tidak terjadi kesalahan dalam pengambil alihan piutang klien. Yang justru akan menimbulkan masalah resiko kredit.

\section{Risiko Hukum}

Risiko hukum dijabarkan menggunakan 13 parameter/indikator yang dapat dilihat selengkapnya pada Lampiran I.1.e dari SE BI No.13/24/DPNP, dapat kita lihat bahwa saat ini di Indonesia belum terdapat peraturan yang mengatur mekanisme perusahaan Anjak Piutang sedetail Lembaga Keuangan Perbankan. Hak tersebut menjadi sebuah resiko untuk kegiatan operasional perusahaan Anjak Piutang.

\section{Risiko Stratejik}

Risiko stratejik dijabarkan menggunakan 10 parameter/indikator yang dapat dilihat selengkapnya pada Lampiran I.1.f dari SE BI No.13/24/DPNP, menunjukkan bahwa dalam kesesuaian dengan kondisi lingkungan bisnis, strategi serta posisi perusahaan saat ini, keberadaan perusahaan anjak piutang saat ini dapat menunjukkan kondisi positif jika perusahaan Anjak Piutang mampu menggandeng Perusahaan Fintech untuk dapat bersinergi dengan perusahaan anjak piutang. Hal tersebut juga sejalan dengan apa yang disampaikan oleh Ketua asosiasi perusahaan pembiayaan Indonesia (APPI), yang dikutip dari bisnis.com. 


\section{Risiko Kepatuhan}

Risiko kepatuhan dijabarkan menggunakan 5 parameter/indikator yang dapat dilihat selengkapnya pada Lampiran I.1.g dari SE BI No.13/24/DPNP, dengan sebagian cuplikannya sebesarnya dalam hal ini agak sedikit unik, karena masih regulasi masih bersifat fleksible maka kaitannya dengan risiko kepatuhan perusahaan anjak piutang bisa dinilai cukup aman, dan tidak rentan terhadap pelanggaran. Hal itu disebabkan oleh aturaaturan yang sifatnya masih fleksible.

\section{Risiko Reputasi}

Risiko kepatuhan dijabarkan menggunakan 10 parameter/indikator yang dapat dilihat selengkapnya pada Lampiran I.1.h dari SE BI No.13/24/DPNP, dapat dilihat bahwa resiko reputasi yang melekat pada perusahaan anjak piutang hampir sama dengan resiko reputasi Lembaga keuangan Bank dan Lembaga Keuangan Lain Non Bank. Dimana Anjak Piutang juga menghadapi resiko reputasi terkait dengan bisnis yang dijalankannya.

\section{Good Corporate Governance}

Good Corporate Governance dibajarkan dengan melihat dari tiga aspek yaitu struktur, proses dan outcome. Struktur perusahaan anjak piutang dapat dikatakan juga masih cukup fleksible karena pengaturan bisnis perusahaan anjak piutang juga belum terlalu ketat seperti lembaga perbankan. Proses bisnis perusahaan anjak piutang saat ini dapat dilihat cukup statis, hanya berkutat dengan pembiayaan pengambil alihan piutang klien, belum detail sesuai teori menjalankan tugas sebagai lembaga yang mengatur piutang klien, hal tersebut karena di Indonesia nilai profesionalitas kadang masih kurang dihargai. Bicara outcomes rasanya sulit dijabarkan, karena untuk sekedar memenuhi output saja kadang sulit, masih banyak piutang yang belum tertagih, masyarakat masih awam menggunakan jasa perusahaan anjak piutang, regulasi perusahaan anjak piutang masih jauh dari kata memadai.

\section{Earning}

Berdasarkan hasil statistik deskriptif menunjukkan nilai minimum variabel Return on Asset (ROA) sebesar 0.01 dan nilai maksimum 10.30. Hasil tersebut menunjukan bahwa Return on Asset (ROA) yang menjadi sampel penelitian ini berkisar $0.01 \%$ sampai $10.30 \%$ dengan rata-rata sebesar $3.96 \%$ dan standar deviasi sebesar $3.00 \%$, hal tersebut menunjukkan bahwa sebenarnya kinerja Perusahaan anjak piutang sudah cukup baik, tetapi masih dibawah rata-rata industry pembiayaan lainnya yang mampu menghasilkan nilai ROA lebih dari angka yang dihasilkan perusahaan anjak piutang.

\section{Capital}

Melihat nilai capital perusahaan Anjak Piutang diatas kita bisa simpulkan bahwa sebenarnya tingkat permodalan di beberapa perusahaan anjak piutang masih sangat jauh dari rata-rata industri pembiayaan. Hal tersebut menunjukkan bahwa investor masih belum banyak yang tertarik untuk menginvestasikan dananya pada perusahaan anjak piutang. 
Tabel 4. Perhitungan Nilai Modal

\begin{tabular}{rcc}
\hline \multicolumn{1}{c}{ No } & Kode & Nilai Modal (dalam ribuan) \\
\hline 1 & ADMF & 29.492 .933 \\
2 & BBLD & 1.129 .541 \\
3 & BPFI & 621.745 \\
4 & CFIN & 4.029 .531 \\
5 & DEFI & 82.660 \\
6 & HDFA & 524.756 \\
7 & MFIN & 1.993 .974 \\
8 & TIFA & 323.771 .910 \\
9 & VRNA & 464.248 .133 \\
10 & BFIN & 4.904 .266 \\
\hline
\end{tabular}

\section{KESIMPULAN}

Berdasarkan analisis kualitatif yang dilakukan dengan Metode RGEC melihat profile masing masing resiko yang melekat pada perusahaan anjak piutang dapat disimpulkan bahwa perusahaan anjak piutang kurang berkembang di Indonesia karena beberapa hal diantaranya resiko kredit yang melekat karena yang kredit yang dibiayai adalah piutang yang berlum dapat tertagih, serta tidak menyertakan agunan lain. Belum terdapat Aturan yang baku yang mengatur mengenai mekanisme termasuk ketika ada kendala yang terkait dengan Hukum pada perusahaan anjak piutang. Hal tersebut menimbulkan investor berfikir seribu kali untuk menginvestasikan dananya.

Selain itu, penyebab perusahaan anjak piutang kurang berkembang di Indonesia berdasarkan analisa yang dilakukan dalam penelitian ini adalah perusahaan Anjak Piutang belum terlalu familiar di Indonesia. Perkembangan jaman dengan munculnya Fintech yang membuat perusahaan anjak piutang mestinya mampu memanfaatkan peluang tersebut, namun belum didukung sumber daya manusia yang mumpuni.

\section{REFERENCES}

Aprianto, Naerul Edwin Kiky. 2017.Anjak Piutang (Factoring) Dalam Ekonomi Islam.Jurnal Ekonomi Islam. Vol. 8, No. 1, Januari - Juni 2017

Bank Indonesia. 1992. UU No. 7 tahun 1992, Tentang Perbankan. Jakarta. 2004.

Fahmi, I. (2014). Bank dan Lembaga Keuangan Lainnya teori dan aplikasi. Bandung: Alfabeta.

Harahab, Sofyan Syafri. 2009. Analisis Kritis atas Laporan Keuangan, Penerbit : Raja Grafindo Persada, Jakarta.

Hasibuan, Melayu. 2008. Dasar-dasar Perbankan. Cetakan pertama. Jakarta : PT Bumi Aksara.

Kasmir, 2014. Bank dan Lembaga Keuangan Lainnya, Edisi Revisi. Cetakan 17, Jakarta: Rajawali Pers.

Keputusan Preseiden Nomor 61 Tahun 1988 tentang Lembaga Pembiayaan Munawir, S. 2007. Analisa Laporan Keuangan, Penerbit : Liberty, Yogyakarta. 
Peraturan Bank Indonesia No. 6/10/PBI/2004 tanggal 12 April 2004 perihal Sistem Penilaian Tingkat Kesehatan Bank Umum. 2004.

Peraturan Bank Indonesia No. 13/1/PBI/2011 perihal Penilaian Tingkat Kesehatan Bank Umum. Jakarta: Bank Indonesia. 2011.

Refmasari,Veranda Aga dan Setiawan, Ngadirin. 2014. PenilaianTingkat Kesehatan Bank Umum Menggunakan Metode RGEC (Risk Profile, Good Corporate Governance, Earnings, dan Capital pada Bank Pembangunan Daerah Provinsi Daerah Istimewa Yogyakarta Tahun 2012. Fakultas Ekonomi Universitas Negeri Yogyakarta.

Regar, R., William, A. A., dan Joula J. R. (2016). Analisis Pemberian Kredit Mikro Terhadap Peningkatan Nasabah Studi Pada PT. Bank Sulutgo Cabang Manado. Jurnal Administrasi Bisnis.

Surat Edaran Bank Indonesia No. 13/24/DNDP/2011 tentang Penilaian Tingkat Kesehatan Bank Umum. Jakarta.

Subagyo, S. F., Badrudin, R., \& Astuti Purnamawati, A. (2002). Bank Dan Lembaga Keuangan Lainnya. Edisi Kedua Cetakan Pertama, Sekolah Tinggi Ilmu Ekonomi YKPN, Yogyakarta.

Subramanyam, K. R. (2017). Financial statement analysis. Edisi Sebelas. Jakarta: Salemba Empat.

Wiwoho, Jamal. (2014). Peran Lembaga Keuangan Bank dan Lembaga Keuangan Bukan Bank Dalam Memberikan Distribusi Keadilan Bagi Masyarakat. Jurnal MMH Jilid 43 No 1. 


\section{LAMPIRAN}

a) Risiko Kredit

"Risiko Kredit dijabarkan dengan menggunakan 12 (dua belas) parameter/indikator yang dapat dilihat selengkapnya pada Lampiran I.1.a dari SE BI No.13/24/DPNP, dengan sebagian cuplikannya dapat dilihat pada tabel berikut:"

\begin{tabular}{|c|c|c|c|c|c|}
\hline \multirow{2}{*}{\multicolumn{6}{|c|}{\begin{tabular}{l|l} 
No & \\
A. Risiko Inheren?
\end{tabular}}} \\
\hline & & & & & \\
\hline \multirow[t]{3}{*}{1.} & \multirow[t]{3}{*}{$\begin{array}{l}\text { Komposisi Portofolio } \\
\text { Aset dan Tingkat } \\
\text { Konsentrasi* }\end{array}$} & a. & $\frac{\text { Aset Per Akun Neraca }}{\text { Total Aset }}$ & & $\begin{array}{l}\text { Aset per akun neraca merupakan akun pada neraca } \\
\text { sesuai yang tertera pada Laporan Bulanan Bank } \\
\text { Umum. } \\
\text { Total aset adalah total aset secara neto (setelah set-off } \\
\text { antar kantor) sesuai yang tertera pada Laporan } \\
\text { Bulanan Bank Umum. }\end{array}$ \\
\hline & & b. & $\frac{\text { Kredit kepada Debitur inti }}{\text { Total Kredit }}$ & & $\begin{array}{l}\text { Kredit kepada debitur inti meliputi kredit kepada pihak } \\
\text { ketiga bukan Bank baik debitur individual maupun grup } \\
\text { diluar pihak terkait dengan kriteria sebagai berikut: } \\
\text { 1) bagi Bank yang memiliki total aset kurang dari atau } \\
\text { sama dengan Rp1 triliun meliputi kredit kepada } 10 \\
\text { debitur besar } \\
\text { 2) bagi Bank yang memiliki total aset lebih besar dari } \\
\text { Rp1 triliun namun lebih kecil atau sama dengan } \\
\text { Rp10 triliun meliputi kredit kepada } 15 \text { debitur/grup } \\
\text { besar } \\
\text { 3) bagi Bank yang memiliki total aset lebih besar dari } \\
\text { Rp10 triliun meliputi kredit kepada } 25 \text { debitur/grup } \\
\text { besar } \\
\text { Total kredit adalah kredit kepada pihak ketiga bukan } \\
\text { Bank. }\end{array}$ \\
\hline & & c. & $\frac{\text { Kredit per Sektor Ekonomi }}{\text { Total Kredit }}$ & & $\begin{array}{l}\text { Kredit per sektor ekonomi adalah kredit kepada Bank } \\
\text { dan pihak ketiga bukan Bank per kategori sektor } \\
\text { ekonomi sebagaimana diatur dalam ketentuan Bank } \\
\text { Indonesia mengenai Laporan Bulanan Bank Umum. } \\
\text { Total kredit adalah kredit kepada Bank dan pihak ketiga } \\
\text { bukan Bank. }\end{array}$ \\
\hline
\end{tabular}

\section{b) Risiko Pasar}

"Resiko pasar dijabarkan dengan menggunakan 17 parameter/indikator yang dapat dilihat selengkapnya pada Lampiran I.1.b dari SE BI No.13/24/DPNP, dengan sebagian cuplikannya dapat dilihat pada tabel berikut :"

\begin{tabular}{|c|c|c|c|c|}
\hline No & & \multicolumn{2}{|c|}{ Parameter/ndikator } & Keterangan \\
\hline \multicolumn{5}{|c|}{ A. Risiko Inheren" } \\
\hline 1. & $\begin{array}{l}\text { Volume dan Komposisi } \\
\text { Portofolio }\end{array}$ & a. & $\frac{\text { Aset Trading, Derivatif, dan FVO }}{\text { Total Aset }}$ & $\begin{array}{l}\text { a) Aset Trading adalah penempatan pada Bank lain, surat } \\
\text { berharga, surat berharga yang dijual dengan janji dibel } \\
\text { kembali (repo), tagihan akseptasi, kredit, dan aset } \\
\text { lainnya dengan kategori pengukuran diperdagangkan } \\
\text { (tradingi. } \\
\text { b) Aset Derivatif adalah seluruh aset transaksi spot dan } \\
\text { derivatif. } \\
\text { c) Aset Fair Value Option (FVO) adalah penempatan pada } \\
\text { Bank lain, surat berharga, surat berharga yang dijual } \\
\text { dengan janii dibeli kembali (repo), tagihan alseptas, } \\
\text { kredit, dan aset lainnya dengan kategori pengukuran } \\
\text { diukur dengan nilai wajar (fair value option). }\end{array}$ \\
\hline & & b. & $\frac{\text { Kewailiban Trading, Derivatif, dan FVO }}{\text { Total Kewajiban }}$ & $\begin{array}{l}\text { a) Kewajiban Trading adalah kewajiban giro, tabungan, } \\
\text { deposito, kewajiban kepada Bank Indonesia, kewajiban } \\
\text { kepada Bank lain, kewajiban repo, kewajiban akseptasi, } \\
\text { surat berharga yang diterbitkan, dan pinjaman yang } \\
\text { diterima dengan kategori trading. } \\
\text { b) Kewajiban Derivatif adalah seluruh kewajiban transaksi } \\
\text { spot dan derivative. } \\
\text { c) Kewajiban Fair Value Option (FVO) adalah kewajiban } \\
\text { giro, tabungan, deposito, kewajiban kepada Bank } \\
\text { Indonesia, kewajiban kepada Bank lain, kewajiban repo, } \\
\text { kewajiban akseptasi, surat berharga yang diterbitkan, } \\
\text { dan pinjaman yang diterima dengan kategori } \\
\text { pengukuran diukur dengan nilai wajar (FVO). }\end{array}$ \\
\hline & & c. & $\frac{\text { Total Structured Product }}{\text { Total Aset }}$ & $\begin{array}{l}\text { a) Total Structured Product adalah seluruh nominal } \\
\text { structured product yang dimiliki oleh Bank sesuai } \\
\text { dengan ketentuan Bank Indonesia mengenai structured } \\
\text { product. } \\
\text { b) Total aset adalah total aset secara neto (setelah set-off } \\
\text { antar kantor) sesuai Laporan Bulanan Bank Umum. }\end{array}$ \\
\hline
\end{tabular}




\section{c) Risiko Likuiditas}

"Risiko likuiditas dijabarkan dengan menggunakan 11 parameter/indikator yang dapat dilihat selengkapnya pada Lampiran I.1.c dari SE BI No.13/24/DPNP, dengan sebagian cuplikannya dapat dilihat pada tabel berikut:"

\begin{tabular}{|c|c|c|c|c|}
\hline No & \multicolumn{3}{|c|}{ Parameterfindikator } & Keterangan \\
\hline \multicolumn{5}{|c|}{ A. Risiko Inheren" } \\
\hline 1. & $\begin{array}{l}\text { Komposisi dari Aset, } \\
\text { Kewajiban, dan } \\
\text { Transaksi Rekening } \\
\text { Administratif }\end{array}$ & a. & $\begin{array}{c}\frac{\text { Aset Likuid Primer dan Aset Likuid Sekunder }}{\text { Total Aset }} \\
\end{array}$ & 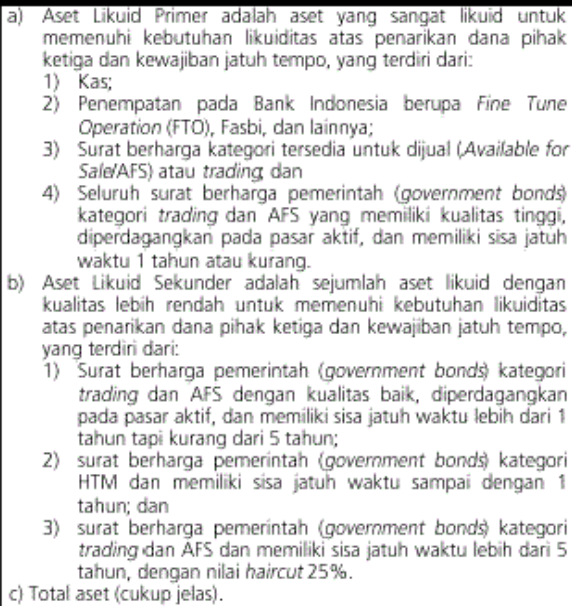 \\
\hline & & b. & $\frac{\text { Aset Likuid Primer dan Aset Likuid Sekunder }}{\text { Pendanaan Jangka Pendek }}$ & $\begin{array}{l}\text { Pendanaan jangka pendek adalah seluruh dana pihak ketiga yang } \\
\text { tidak memiliki jatuh tempo dan/atau dana pihak ketiga yang } \\
\text { memiliki jatuh tempo } 1 \text { tahun atau kurang. }\end{array}$ \\
\hline
\end{tabular}

\section{d) Risiko Operasional}

"Risiko operasional dijabarkan dengan menggunakan 15 parameter/indikator yang dapat dilihat selengkapnya pada Lampiran I.1.d dari SE BI No.13/24/DPNP, dengan sebagian cuplikannya dapat dilihat pada tabel berikut:"

\begin{tabular}{|c|c|c|c|}
\hline No & & Parameter/indikator & Keterangan \\
\hline \multicolumn{4}{|c|}{ A. Risiko Inheren" } \\
\hline 1. & \begin{tabular}{|l} 
Karakteristik dan \\
Kompleksitas Bisnis
\end{tabular} & $\begin{array}{l}\text { a. Skala usaha dan struktur organisasi Bank } \\
\text { b. Kompleksitas proses bisnis dan keragaman produkjjasa } \\
\text { c. Corporate action dan pengembangan bisnis baru } \\
\text { d. Outsourcing }\end{array}$ & $\begin{array}{l}\text { Tingginya kompleksitas bisnis dan tingkat keragaman produk } \\
\text { Bank akan menimbulkan kerumitan dan variasi proses kerja } \\
\text { baik secara manual maupun otomasi sehingga berpotensi } \\
\text { menimbulkan terjadinya gangguarvkerugian operasional. }\end{array}$ \\
\hline 2. & Sumber Daya Manusia & $\begin{array}{l}\text { a. Penerapan Manajemen Sumber Daya Manusia } \\
\text { b. Kegagalan karena Faktor Manusia (Human Error) }\end{array}$ & $\begin{array}{l}\text { Manajemen sumber daya manusia yang tidak efektif dapat } \\
\text { mengakibatkan potensi timbulnya gangguan/kerugian } \\
\text { operasional Bank }\end{array}$ \\
\hline 3. & $\begin{array}{l}\text { Teknologi Informasi } \\
\text { dan Infrastruktur } \\
\text { Pendukung }\end{array}$ & $\begin{array}{l}\text { a. Kompleksitas Teknologi Informasi } \\
\text { b. Perubahan Sistem TI } \\
\text { c. Kerentanan Sistem TI terhadap ancaman dan serangan TI } \\
\text { d. Maturity Sistem TI } \\
\text { e. Kegagalan Sistem TI } \\
\text { f. Keandalan Infrastruktur Pendukung }\end{array}$ & $\begin{array}{l}\text { Teknologi informasi yang sudah tidak memadai dan/atau } \\
\text { pengelolaan yang tidak efektif dan efisien dapat } \\
\text { menyebabkan timbulnya kerugian bagi Bank. }\end{array}$ \\
\hline 4. & Fraud & $\begin{array}{l}\text { a. Fraud Internal } \\
\text { b. Fraud Eksternal }\end{array}$ & $\begin{array}{l}\text { Penilaian fraud dilakukan terhadap frekuensi/materialitas } \\
\text { fraud yang telah terjadi pada periode penilaian sebelumnya, } \\
\text { termasuk potensi fraud yang dapat timbul dari kelemahan } \\
\text { pada aspek bisnis, SDM, teknologi informasi dan kejadian } \\
\text { eksternal. }\end{array}$ \\
\hline 5. & Kejadian Eksternal & $\begin{array}{l}\text { Frekuensi dan materialitas kejadian eksternal yang berdampak } \\
\text { terhadap kegiatan operasional Bank }\end{array}$ & $\begin{array}{l}\text { Kejadian eksternal tersebut misalnya terorisme, kriminalitas, } \\
\text { pandemik dan bencana alam Lokasi dan kondisi geografis } \\
\text { Bank }\end{array}$ \\
\hline \multicolumn{4}{|c|}{ B. Kualitas Penerapan Manajemen Risiko } \\
\hline 1 & \multicolumn{3}{|c|}{$\begin{array}{l}\text { Tata Kelola Risiko (Risk Governance) mencakup evaluasi terhadap: (i) perumusan tingkat Risiko yang akan diambil (risk appetite) dan toleransi Risiko (risk } \\
\text { tolerance) dan (ii) kecukupan pengawasan aktif oleh Dewan Komisaris dan Direksi termasuk pelaksanaan kewenangan dan tanggung jawab Dewan } \\
\text { Komisaris dan Direksi. }\end{array}$} \\
\hline 2 & \multicolumn{3}{|c|}{$\begin{array}{l}\text { Kerangka Manajemen Risiko mencakup evaluasi terhadap: (i) strategi Manajemen Risiko yang searah dengan tingkat Risiko yang akan diambil dan toleransi } \\
\text { Risiko; (ii) kecukupan perangkat organisasi dalam mendukung terlaksananya Manajemen Risiko secara efektif termasuk kejelasan wewenang dan tanggung } \\
\text { jawab; dan (iii) kecukupan kebijakan, prosedur dan penetapan limit. }\end{array}$} \\
\hline 3 & \multicolumn{3}{|c|}{ Proses Manajemen Risiko, Sistem Informasi, dan Sumber Daya Manusia mencakup evaluasi terhadap: (i) proses identifikasi, pengukuran, pemantauan, dan } \\
\hline
\end{tabular}




\section{e) Risiko Hukum}

Risiko hukum dijabarkan menggunakan 13 parameter/indikator yang dapat dilihat selengkapnya pada Lampiran I.1.e dari SE BI No.13/24/DPNP, dengan sebagian cuplikannya dapat dilihat pada tabel berikut.

\begin{tabular}{|c|c|c|c|}
\hline \multirow{2}{*}{ No } & \multicolumn{2}{|r|}{ Parameter/ndikator } & \multirow[t]{2}{*}{ Keterangan } \\
\hline & kisiko Inheren"? & & \\
\hline 1. & Faktor Litigasi & $\begin{array}{l}\text { a. Besarnya nominal gugatan yang diajukan atau estimasi } \\
\text { kerugian yang mungkin dialami oleh Bank akibat dari gugatan } \\
\text { tersebut dibandingkan dengan modal Bank. } \\
\text { b. Besarnya kerugian yang dialami oleh Bank karena suatu } \\
\text { putusan dari pengadilan yang telah memiliki kekuatan hukum } \\
\text { tetap dibandingkan dengan modal Bank. } \\
\text { c. Dasar dari gugatan yang terjadi dan pihak yang } \\
\text { tergugat/menggugat Bank dalam suatu gugatan yang diajukan } \\
\text { serta tindakan dari manajemen atas suatu gugatan yang } \\
\text { diajukan. } \\
\text { d. Kemungkinan timbulnya gugatan yang serupa karena adanya } \\
\text { standar perjanjian yang sama dan estimasi total kerugian yang } \\
\text { mungkin timbul dibandingkan dengan modal Bank. }\end{array}$ & $\begin{array}{l}\text { Litigasi dapat terjadi karena adanya gugatan atau } \\
\text { tuntutan dari pihak ketiga kepada Bank maupun } \\
\text { gugatan atau tuntutan yang diajukan kepada pihak } \\
\text { ketiga baik melalui pengadilan maupun diluar } \\
\text { pengadilan. Gugatan atau tuntutan tersebut pada } \\
\text { dasarnya menimbulkan biaya yang dapat merugikan } \\
\text { kondisi Bank. }\end{array}$ \\
\hline 2. & $\begin{array}{l}\text { Faktor } \\
\text { Perikatan }\end{array}$ & $\begin{array}{l}\text { a. Tidak terpenuhinya syarat sahnya perjanjian. } \\
\text { b. Terdapat kelemahan klausula perjanjian dan/atau tidak } \\
\text { terpenuhinya persyaratan yang telah disepakati. } \\
\text { c. Pemahaman para pihak terkait dengan perjanjian, terutama } \\
\text { mengenai risiko-risiko yang ada dalam suatu transaksi yang } \\
\text { kompleks dan menggunakan istilahistilah yang sulit dipahami } \\
\text { atau tidak lazim bagi masyarakat umum. } \\
\text { d. Tidak dapat dilaksanakannya suatu perjanjian baik untuk } \\
\text { keseluruhan maupun sebagian. } \\
\text { e. Keberadaan dokumen pendukung terkait perjanjian yang } \\
\text { dilakukan oleh Bank dengan pihak ketiga. } \\
\text { f. Pengkinian dan review dari penggunaan standar perjanjian } \\
\text { oleh Bank dan/atau pihak independen. } \\
\text { g. Penggunaan pilihan hukum Indonesia atas perjanjian yang } \\
\text { diadakan oleh Bank dan juga penggunaan forum penyelesaian } \\
\text { sengketa. }\end{array}$ & $\begin{array}{l}\text { Kelemahan perikatan yang dilakukan oleh Bank } \\
\text { merupakan sumber terjadinya permasalahan atau } \\
\text { sengketa di kemudian hari yang dapat menimbulkan } \\
\text { potensi Risiko Hukum bagi Bank. }\end{array}$ \\
\hline 3. & $\begin{array}{l}\text { Faktor } \\
\text { Ketiadaan/Perubahan } \\
\text { Perundang-Undangan }\end{array}$ & $\begin{array}{l}\text { a. Jumlah dan nilai nominal dari total produk Bank yang belum } \\
\text { diatur oleh peraturan perundang-undangan secara jelas dan } \\
\text { produk tersebut cenderung memiliki tingkat kompleksitas yang }\end{array}$ & $\begin{array}{l}\text { Ketiadaan peraturan perundang-undangan terutama } \\
\text { atas produk yang dimiliki Bank atau transaksi yang } \\
\text { dilakukan Bank akan mengakibatkan produk tersebut }\end{array}$ \\
\hline
\end{tabular}

Sebagian matrik parameter penilaian risiko hukum (sumber: Lampiran I.1.e SE BI No.13/24/DPNP)

\section{f) Risiko Stratejik}

Risiko stratejik dijabarkan menggunakan 10 parameter/indikator yang dapat dilihat selengkapnya pada Lampiran I.1.f dari SE BI No.13/24/DPNP, dengan sebagian cuplikannya dapat dilihat pada tabel berikut.

\begin{tabular}{|c|c|c|c|}
\hline No & & Parameter/Indikator & Keterangan \\
\hline \multicolumn{4}{|c|}{ A. Risiko Inheren? } \\
\hline 1. & $\begin{array}{l}\text { Kesesuaian Strategi } \\
\text { dengan Kondisi } \\
\text { Lingkungan Bisnis }\end{array}$ & $\begin{array}{l}\text { Penetapan tujuan stratejik perlu mempertimbangkan faktor } \\
\text { internal dan eksternal bisnis Bank: } \\
\text { a. Faktor internal, antara lain: } \\
\text { 1) Visi, misi, dan arah bisnis yang ingin dicapai Bank; } \\
\text { 2) Kultur organisasi, terutama apabila penetapan tujuan } \\
\text { stratejik mensyaratkan perubahan struktur organisasi dan } \\
\text { penyesuaian proses bisnis; } \\
\text { 3) Faktor kemampuan organisasi yang mencakup antara lain } \\
\text { sumber daya manusia, infrastruktur, dan sistem informasi } \\
\text { manajemen; dan } \\
\text { 4) Tingkat toleransi risiko yaitu tingkat kemampuan } \\
\text { keuangan Bank menyerap risiko. } \\
\text { b. Faktor eksternal, antara lain: } \\
\text { 1) Kondisi makroekonomi; } \\
\text { 2) Perkembangan teknologi; dan } \\
\text { 3) Tingkat persaingan usaha. }\end{array}$ & $\begin{array}{l}\text { Penilaian parameter antara lain untuk mengukur } \\
\text { apakah penetapan sasaran strategis oleh Dewan } \\
\text { Direksi didukung dengan kondisi internal maupun } \\
\text { eksternal dari lingkungan bisnis Bank. }\end{array}$ \\
\hline 2. & $\begin{array}{l}\text { Strategi Berisiko Tinggi } \\
\text { dan Strategi Berisiko } \\
\text { Rendah }\end{array}$ & $\begin{array}{l}\text { a. Strategi berisiko rendah adalah strategi di mana Bank } \\
\text { melakukan kegiatan usaha pada pangsa pasar dan nasabah } \\
\text { yang telah dikenal sebelumnya atau menyediakan produk yang } \\
\text { bersifat tradisional sehingga tingkat pertumbuhan usaha } \\
\text { cenderung stabil dan dapat diprediksi. } \\
\text { b. Strategi berisiko tinggi adalah strategi di mana Bank berencana } \\
\text { masuk dalam area bisnis baru, baik pangsa pasar, produk atau } \\
\text { jasa, atau nabasah baru. }\end{array}$ & $\begin{array}{l}\text { Tingkat risiko inheren dapat ditimbulkan pula oleh } \\
\text { pilihan strategi Bank. }\end{array}$ \\
\hline 3. & Posisi Bisnis Bank & $\begin{array}{l}\text { Penilaian antara lain didasarkan pada: } \\
\text { a. Pasar di mana Bank melaksanakan kegiatan usaha; } \\
\text { b. Kompetitor dan keunggulan kompetitif; } \\
\text { c. Efisiensi dalam melaksanakan kegiatan usaha; } \\
\text { d. Diversifikasi kegiatan usaha dan cakupan wilayah operasional; } \\
\text { e. Kan Kondisi makro ekonomi dan dampaknya pada kondisi Bank. }\end{array}$ & $\begin{array}{l}\text { Seberapa besar tingkat keberhasilan/kegagalan Bank } \\
\text { dalam mencapai tujuan dapat dinilai berdasarkan } \\
\text { posisi Bank di pasar dan keunggulan kompetitif yang } \\
\text { dimiliki, baik terhadap peer group maupun industri } \\
\text { perbankan secara keseluruhan. }\end{array}$ \\
\hline
\end{tabular}


Rani Eka Diansari dan Vidya Vitta Adhivinna

Mengapa Perusahaan Anjak Piutang Kurang Berkembang Di Indonesia?

(Dilihat Dengan Analisis Risk Profile, Good Governance, Earning Dan Capital (RGEC))

\section{g) Risiko Kepatuhan}

"Risiko kepatuhan dijabarkan menggunakan 5 parameter/indikator yang dapat dilihat selengkapnya pada Lampiran I.1.g dari SE BI No.13/24/DPNP, dengan sebagian cuplikannya dapat dilihat pada tabel berikut:"

\begin{tabular}{|c|c|c|c|}
\hline No & & Parameter/indikator & Keterangan \\
\hline \multicolumn{4}{|c|}{ A. Risiko Inheren? } \\
\hline 1. & $\begin{array}{l}\text { Jenis dan Signifikansi } \\
\text { Pelanggaran yang } \\
\text { Dilakukan }\end{array}$ & $\begin{array}{l}\text { a. Jumlah sanksi denda kewajiban membayar yang } \\
\text { dikenakan kepada Bank dari otorita. } \\
\text { b. Jenis pelanggaran atau ketidakpatuhan yang dilakukan } \\
\text { oleh Bank. }\end{array}$ & $\begin{array}{l}\text { Cakupan pelanggaran merupakan pelanggaran terhadap } \\
\text { ketentuan yang berlaku dan komitmen kepada Bank } \\
\text { Indonesia termasuk sanksi yang dikenakan atas } \\
\text { pelangaran yang dilakukan oleh Bank. }\end{array}$ \\
\hline 2. & $\begin{array}{l}\text { Frekuensi Pelanggaran } \\
\text { yang Dilakukan atau Track } \\
\text { Record Kepatuhan Bank }\end{array}$ & $\begin{array}{l}\text { a. Jenis dan frekuensi pelanggaran yang sama yang } \\
\text { ditemukan setiap tahunnya dalam } 3 \text { tahun terakhir. } \\
\text { b. Signifikansi tindak lanjut Bank atas temuan tersebut. }\end{array}$ & $\begin{array}{l}\text { Frekuensi lebih bersifat historis dengan melihat trend } \\
\text { kepatuhan Bank selama } 3 \text { tahun terakhir untuk } \\
\text { mengetahui apakah jenis pelanggaran yang dilakukan } \\
\text { berulang ataukah memang atas kesalahan tersebut tidak } \\
\text { dilakukan perbaikan signifikan oleh Bank. }\end{array}$ \\
\hline 3. & $\begin{array}{l}\text { Pelanggaran Terhadap } \\
\text { Ketentuan atas Transaksi } \\
\text { Keuangan Tertentu }\end{array}$ & $\begin{array}{l}\text { Frekuensi pelanggaran atas ketentuan pada transaksi } \\
\text { keuangan tertentu karena tidak sesuai dengan standar yang } \\
\text { berlaku umum. }\end{array}$ & $\begin{array}{l}\text { Sebagai contoh adalah pelanggaran terhadap antara lain } \\
\text { UCP, ISDA, ICC, ataupun standar-standar lainnya yang } \\
\text { berlaku secara umum pada sektor keuangan. }\end{array}$ \\
\hline \multicolumn{4}{|c|}{ 8. Kualitas Penerapan Manajemen Risiko } \\
\hline 1 & \multicolumn{3}{|c|}{$\begin{array}{l}\text { Tata Kelola Risiko (Risk Governance) mencakup evaluasi terhadap: (i) perumusan tingkat Risiko yang akan diambil (risk appetite) dan toleransi Risiko (risk } \\
\text { tolerance) dan (ii) kecukupan pengawasan aktif oleh Dewan Komisaris dan Direksi termasuk pelaksanaan kewenangan dan tanggung jawab Dewan } \\
\text { Komisaris dan Direksi. }\end{array}$} \\
\hline 2 & \multicolumn{3}{|c|}{$\begin{array}{l}\text { Kerangka Manajemen Risiko mencakup evaluasi terhadap: (i) strategi Manajemen Risiko yang searah dengan tingkat Risiko yang akan diambil dan toleransi } \\
\text { Risiko; (ii) kecukupan perangkat organisasi dalam mendukung terlaksananya Manajemen Risiko secara efektif termasuk kejelasan wewenang dan tanggung } \\
\text { jawab; dan (iii) kecukupan kebijakan, prosedur dan penetapan limit. }\end{array}$} \\
\hline 3 & \multicolumn{3}{|c|}{$\begin{array}{l}\text { Proses Manajemen Risiko, Sitem Informasi, dan Sumber Daya Manusia mencakup evaluasi terhadap: (1) proses identifikasi, pengukuran, pemantauan, dan } \\
\text { pengendalian risiko; (ii) kecukupan sistem informasi Manajemen Risiko; dan (iii) kecukupan kuantitas dan kualitas sumber daya manusia dalam mendukung } \\
\text { efektivitas proses manajemen Risiko. }\end{array}$} \\
\hline 4 & \multicolumn{3}{|c|}{$\begin{array}{l}\text { Sistem Pengendalian Risiko mencakup evaluasi terhadap: (i) kecukupan Sistem Pengendalian Intern dan (ii) kecukupan kaji ulang oleh pihak independen } \\
\text { (independent review) dalam Bank baikoleh Satuan Kerja Manajemen Risiko (SKMR) maupun oleh Satuan Kerja Audit Intern (SKAl). }\end{array}$} \\
\hline
\end{tabular}

*) Merupakan parameteríndikator minimal dan Bank dapat menambah parameterlindikator lainnya sesuai dengan karakteristik dan kompleksitas usaha Bank. Penilaian dilakukan per posisi dan trendselama 12 bulan terakhir untuk parameter/indikator yang bersifat kuantitatif.

Dalam menilai Tingkat Kesehatan Bank secara Konsolidasi dapat menggunakan paramaterfindikator penilaian Tingkat Kesehatan Bank secara individual, yang wajilb disesuaikan dengan skala, karakteristik dan kompleksitas usaha Perusahaan Anak.

\section{h) Risiko Reputasi}

Risiko kepatuhan dijabarkan menggunakan 10 parameter/indikator yang dapat dilihat selengkapnya pada Lampiran I.1.h dari SE BI No.13/24/DPNP, dengan sebagian cuplikannya dapat dilihat pada tabel berikut:

\begin{tabular}{|c|c|c|c|}
\hline No & & Parameter/ndikator & Keterangan \\
\hline \multicolumn{4}{|c|}{ A. Risiko Inheren" } \\
\hline 1. & $\begin{array}{l}\text { Pengaruh Reputasi dari } \\
\text { Pemilik Bank dan } \\
\text { Perusahaan Terkait }\end{array}$ & $\begin{array}{l}\text { a. Kredibilitas pemilik dan perusahaan terkait. } \\
\text { b. Kejadian reputasi (reputational event) pada pemilik dan } \\
\text { perusahaan terkait. }\end{array}$ & $\begin{array}{l}\text { Pengaruh reputasiberita negatif dari pemilik Bank dan/atau } \\
\text { perusahaan terkait dengan Bank merupakan salah satu } \\
\text { faktor yang dapat menyebabkan peningkatan Risiko } \\
\text { Reputasi pada Bank. }\end{array}$ \\
\hline 2. & Pelanggaran Etika Bisnis & $\begin{array}{l}\text { Pelanggaran etika terlihat antara lain melalui: } \\
\text { a. transparansi informasi keuangar, dan } \\
\text { b. kerjasama bisnis dengan stakeholders lainnya. }\end{array}$ & $\begin{array}{l}\text { Dalam hal ini yang perlu diperhatikan apabila Bank } \\
\text { melakukan pelanggaran terhadap etika/norma-norma } \\
\text { bisnis yang berlaku secara umum. }\end{array}$ \\
\hline 3. & $\begin{array}{l}\text { Kompleksitas Produk dan } \\
\text { Kerjasama Bisnis Bank }\end{array}$ & $\begin{array}{l}\text { a. Jumlah dan tingkat penggunaan nasabah atas produk } \\
\text { Bank yang kompleks. } \\
\text { b. Jumlah dan materialitas kerjasama Bank dengan mitra } \\
\text { bisnis. }\end{array}$ & $\begin{array}{l}\text { Produk yang kompleks dan kerjasama dengan mitra bisnis } \\
\text { dapat terekspos pada Risiko Reputasi apabila terdapat } \\
\text { kesalahpahaman penggunaan produk/jasa atau } \\
\text { pemberitaan negatif pada mitra bisnis, antara lain pada } \\
\text { produk bancassurance dan reksadana. }\end{array}$ \\
\hline 4. & $\begin{array}{l}\text { Frekuensi, Materialitas dan } \\
\text { Eksposur Pemberitaan } \\
\text { Negatif Bank }\end{array}$ & $\begin{array}{l}\text { a. Frekuensi dan materialitas pemberitaan. } \\
\text { b. Jenis media dan ruang lingkup pemberitaan }\end{array}$ & $\begin{array}{l}\text { Frekuensi, jenis media, dan materialitas pemberitaan } \\
\text { negatif Bank, meliputi juga pengurus Bank, yang diukur } \\
\text { selama periode penilaian. }\end{array}$ \\
\hline 5. & $\begin{array}{l}\text { Frekuensi dan Materialitas } \\
\text { Keluhan Nasabah }\end{array}$ & $\begin{array}{l}\text { a. Frekuensi keluhan nasabah. } \\
\text { b. Materialitas keluhan nasabah. }\end{array}$ & Keluhan nasabah diukur selama periode penilaian. \\
\hline \multicolumn{4}{|c|}{ B. Kualitas Penerapan Manajemen Risiko } \\
\hline 1 & \multicolumn{3}{|c|}{$\begin{array}{l}\text { Tata Kelola Risiko (Risk Governance) mencakup evaluasi terhadap: (i) perumusan tingkat Risiko yang akan diambil (risk appetite) dan toleransi Risiko (risk } \\
\text { tolerance) dan (ii) kecukupan pengawasan aktif oleh Dewan Komisaris dan Direksi termasuk pelaksanaan kewenangan dan tanggung jawab Dewan } \\
\text { Komisaris dan Direksi. }\end{array}$} \\
\hline 2 & \multicolumn{3}{|c|}{$\begin{array}{l}\text { Kerangka Manajemen Risiko mencakup evaluasi terhadap: (i) strategi Manajemen Risiko yang searah dengan tingkat Risiko yang akan diambil dan toleransi } \\
\text { Risiko; (ii) kecukupan perangkat organisasi dalam mendukung terlaksananya Manajemen Risiko secara efektif termasuk kejelasan wewenang dan tanggung } \\
\text { jawab; dan (iii) kecukupan kebijakan, prosedur dan penetapan limit. }\end{array}$} \\
\hline 3 & \multicolumn{3}{|c|}{ Proses Manajemen Risiko, Sistem Informasi, dan Sumber Daya Manusia mencakup evaluasi terhadap: (i) proses identifikasi, p } \\
\hline
\end{tabular}

